\title{
Violence against teachers of public elementary II schools
}

\author{
Violência contra os professores das escolas públicas fundamental II \\ Violencia contra los profesores de escuelas públicas de primaria ii
}

\author{
Cléa Adas Saliba GARBIN ${ }^{1}$ \\ Tânia Adas Saliba ROVIDA ${ }^{2}$ \\ Adriana Alves COSTA ${ }^{3}$ \\ Artênio José Isper GARBIN ${ }^{4}$ \\ ${ }^{1}$ PhD in Forensic and Ethics Dentistry, Department of Child and Social Dentistry, School of Dentistry at Araçatuba, \\ UNESP - Univ. Estadual Paulista, Brasil, Araçatuba - SP, Brazil \\ ${ }^{2} \mathrm{PhD}$ in Forensic and Ethics Dentistry. Department of Child and Social Dentistry, School of Dentistry at Araçatuba, \\ UNESP - Univ. Estadual Paulista, Brasil, Araçatuba - SP, Brazil \\ ${ }^{3}$ Masters in Social and Preventive Dentistry Graduate Program, School of Dentistry at Araçatuba, \\ UNESP - Univ. Estadual Paulista, Brasil, Araçatuba - SP, Brazil \\ ${ }^{4}$ PhD in Orthodontics. Professor, Department of Child and Social Dentistry, School of Dentistry at Araçatuba, \\ UNESP - Univ. Estadual Paulista, Brasil, Araçatuba - SP, Brazil
}

\begin{abstract}
The aim of was to determine the prevalence of cases of violence against teachers, in public schools in a city in São Paulo State. This is a cross-sectional, analytical, quantitative and qualitative study. Being a total of 148 teachers and consenting answered a questionnaire. Of these, 109 agreed to participate, $43 \%$ reported having experienced some form of violence at school and of the affirmative cases, $85 \%$ said that verbal abuse is more common. It is concluded that violence is present in the school setting, due to various factors that leads to an inversion of values, which generates disrespect against teachers.
\end{abstract}

Descriptors: Exposure to Violence; Education, Primary and Secondary; Adolescent.

\section{Resumo}

O objetivo foi determinar a prevalência de casos de violência contra professores, nas escolas públicas em uma cidade no Estado de São Paulo. Este é um estudo transversal, analítico, quantitativo e qualitativo. Sendo um total de 148 professores e consentia responderam a um questionário. Destes, 109 aceitaram participar, 43\% relataram ter sofrido algum tipo de violência na escola e dos casos afirmativos, $85 \%$ disseram que o abuso verbal é mais comum. Concluise que a violência está presente no ambiente escolar, devido a vários fatores que leva a uma inversão de valores, o que gera desrespeito contra os professores.

Descritores: Exposição à Violência; Ensino Fundamental e Médio; Adolescente.

\section{Resumen}

El objetivo de fue determinar la prevalencia de casos de violencia contra los docentes, en las escuelas públicas en una ciudad en el estado de São Paulo. Se trata de un estudio transversal, analítico, cuantitativo y cualitativo. Siendo un total de 148 profesores y consintiendo contestado un cuestionario. De ellos, 109 aceptaron participar, el 43\% reportó haber experimentado alguna forma de violencia en la escuela y de los casos afirmativos, $85 \%$ dijo que el abuso verbal es más común. Se concluye que la violencia está presente en el entorno escolar, debido a diversos factores que conduce a una inversión de valores, que genera la falta de respeto contra los maestros.

Descriptores: Exposición a la Violência; Educación Primaria y Secundaria; Adolescente. 


\section{INTRODUCTION}

According to the Ministry of Health, through the dissemination of information from the Surveillance System for Violence and Accidents, in order to collect data and generate information on accidents and violence to support public health policies directed at these aggressions in the years of 2008 and 2009, it shows that youth violence is a major cause of morbidity and mortality in this range, and the most common sites of occurrence appointed were the public road, the home and the school ${ }^{1}$.

The types of violence practiced by most young people are: physical violence (qualified by the use of force or visible acts between students or members of the school); verbal violence (aggressive acts in situations of oppression, humiliation, insults, profanity, between students themselves in and out of schools); symbolic violence (attitudes practiced by students or members of the school, in the form of discriminatory conduct on the others) and Bullying (manifested by verbal abuse, offensive and derogatory nicknames, humiliation, exclusion and bullying the victim) $)^{2}$.

The school, like all institutions of society, is also affected by this phenomenon, especially when the boundaries between it and the outside world are weakened. This should prepare the student to deal with life situations from the dialogue and the exercise of citizenship ${ }^{3}$.

However, there is consensus that education begins at home, but unfortunately the family gave up the dialogue and values traditionally offered by it. Young people who live with family disunity exposes the problems experienced, most often in the form of violence. Often parents confront teachers in front of their children, making them undertake no limit in dealing with their peers, feeding a feeling of grandeur before those who they should respect and obey ${ }^{4-6}$.

School violence, treated before as a simple matter of discipline, came to be regarded as a manifestation of juvenile antisocial behavior and expression. Today, it is perceived in a much broader way in outlooks that express phenomena such as globalization and social exclusion which require analyzes that are not restricted to offenses committed by young students or the violence of social relations among them ${ }^{7,8}$.

Teachers cannot cope with the phenomenon that occurs within the environment in which it proposed to educate students. The result is that sometimes the victims themselves are and end up living in situations of risk such as disrespect, disinterest and verbal and physical abuse, a situation that makes the learning environment impossible, even harming students who did not commit the violence ${ }^{9-13}$.
The aggressiveness with which students are directed to teachers causes them to give up their profession for fear of the students. This causes the decline of the prestige of the self on young people, they feel insecure and unprepared, are no longer a model to be copied, and are often cited by students as a professional failure ${ }^{8,14}$.

The most common offenses towards the teachers are through name calling and graffiti on the walls, classrooms, bathrooms or hallways of the schools. The school is the work environment of the teacher, but it is also where they configure their health-illness process, with frequent cases of absence from work for medical reasons, depression, among others $^{11,15}$.

The threats may or may not materialize into physical violence, which creates a climate of everyday stress. Reports indicate that some of these threats effectively turn into physical abuse by students when, for example, they are put out of the classroom, suspended and / or banned from entering for being late. $^{14}$

Teachers claim that young people are losing basic values related to spirituality, honesty, education and are replacing them with the material, putting money in the first place. Another fact arising from this change in values is the loss of authority of teachers to the dealers and gang leaders in the school, where students defy and despise the economic condition of teachers, comparing it to theirs ${ }^{16}$.

Although the issue of violence experienced by teachers in schools is of paramount importance, given the consequences generated for these health professionals, little research has been concerned with addressing the topic ${ }^{15}$. There are still sparse statistics that portray this reality, which justifies this study, and seeks to determine the prevalence of situations of violence perpetrated by students against teachers of elementary school II in public schools in a municipality in the State of São Paulo.

\section{MATERIAL AND METHOD}

This is a cross-sectional, analytical and quantitative and qualitative study.

\section{- Participants}

All State Public Elementary II Schools from a city in the state of São Paulo, Brazil $(n=22)$, all the teachers $(n=148)$, and the 8th grade units that were invited to participate were visited.

\section{- Instruments}

The instrument consisted of a self-administered, semi-structured questionnaire with open and closed assertions regarding the prevalence of situations of 
violence committed by students against teachers, after obtaining the signed Informed Consent. The same was especially prepared for the research and pre-testing. The instrument passed the relevant adjustments.

\section{- Procedure}

The study was approved by the state secretary of education. The visits were conducted after approval by the school board. A questionnaire was administered to teachers in the 8th grade.

\section{- Data Analysis}

The collected data were entered and analyzed using the Epi Info version 3.5.1. Windows ${ }^{\circledR}$ statistical software by means of frequency distribution. The statistical analysis was performed with the Fisher's exact test with the BioEstat 5.0 program.

Regarding the qualitative analysis, the Content Analysis ${ }^{17}$ technique was used, through categorization of responses and in-depth analysis of the manifest content of the social actions involved. The Content Analysis, as a technique for data processing, has the same logic of quantitative methodologies, since it is the encrypted search interpretation of qualitative materials $^{18}$. Historically, the Content Analysis has oscillated between the classical rigor of supposed objectivity of numbers and fecundity of subjectivity, thus in its origin, it is a victim of alleged objectivity that the numbers and measures offer ${ }^{18}$.

\section{RESULTS}

Of the total of approximately 148 professionals, 109 agreed to participate in the study, and 97\% had a higher education. Regarding gender, $77 \%$ were women, $21 \%$ men and $2 \%$ did not answer. Teachers are distributed in the following age groups: 20-30 years $(10 \%), 31-40$ years $(28.5 \%), 41-50$ years $(41.3 \%), 51-60$ years $(13.7 \%), 61-70$ years $(3.7 \%)$ and no response $(2.8 \%)$. The qualitative data were analyzed and quantified according to the categorization. In relation to what they mean by violence in schools, the majority (70\%) says it involves verbal, physical and psychological aggression.

Table 1. Numeric distribution and percentage of categories, according to the concept of violence in schools, in the opinion of teachers. Araçatuba SP-2012

\begin{tabular}{|c|c|c|}
\hline CATEGORIES & $\mathbf{n}$ & $\%$ \\
\hline $\begin{array}{l}\text { "VERBAL, PHYSICAL AND PSYCHOLOGICAL } \\
\text { AGGRESSION". }\end{array}$ & 76 & 70 \\
\hline $\begin{array}{l}\text { "LACK OF BOUNDARIES, BOUNDARIES, EDUCATION } \\
\text { AND THREATS } \\
\text { ENUSTAINED IN } \\
\text { ENVIRONMENT". }\end{array}$ & 25 & $\mathbf{2 3}$ \\
\hline $\begin{array}{l}\text { "THE INDISCIPLINE OF STUDENTS AND THE WAY THEY } \\
\text { CHALLENGE THE TEACHER'S AUTHORITY". }\end{array}$ & 5 & 4 \\
\hline “LACK OF FAMILY STRUCTURE”. & 3 & 3 \\
\hline TOTAL & 109 & 100 \\
\hline
\end{tabular}

Regarding the difficulty of controlling indiscipline in the classroom, $72.5 \%$ said they could maintain control and $27.5 \%$ said they could not do. A reasonable percentage $(43 \%)$, in the present work, has suffered some kind of violence at school and in these cases, verbal abuse was the most common (85\%). Regarding the gender of the perpetrator, $42.5 \%$ were male and $49 \%$ claim to be of both genders.

Regarding the frequency of cases of violence, $82.5 \%$ said these episodes at work are rare and $17.5 \%$ claim them to be commonplace. With regards to the causes that can lead the student to assault a teacher, $43 \%$ of the respondents attributed this to family dysfunction as seen in Table 2 .

Table 2. Numeric distribution and percentage of categories, according to the causes of violence against the teacher, in the opinion of the interviewed. Araçatuba SP-2012

\begin{tabular}{lrr}
\hline \multicolumn{1}{c}{ CATEGORIES } & n & $\%$ \\
\hline "FAMILY DISTRUCTURE". & 47 & 43 \\
"LACK OF RESPECT, EDUCATION AND LIMITS". & 44 & 40 \\
"FOR NOT LIKING TO HAVE ATTENTION CALLED TO". & 7 & 6 \\
"DRUGS AND ALCOHOLIC BEVERAGES". & 4 & 4 \\
"LACK OF COMMITMENT TO SCHOOL". & 3 & 3 \\
"EXCESSIVE RIGHTS THAT ARE IMPOSSED". & 2 & 2 \\
NOT ANSWERED & 2 & 2 \\
TOTAL & 109 & 100 \\
\hline
\end{tabular}

Regarding the attitude taken before an act of violence, $40 \%$ would inform the school board and $38 \%$ would talk with the student to help him, according to Table 3 .

Table 3. Numeric distribution and percentage of categories, depending on the attitude taken towards an act of violence, in the opinion of teachers. Araçatuba SP-2012.

\begin{tabular}{lccc}
\hline \multicolumn{1}{c}{ CATEGORIES } & n & $\%$ \\
\hline "REPORT THE DIRECTION, THE RESPONSIBLE AND & 44 & 40 \\
RELEVANT BODIES". & & \\
"DIALOGUE WITH THEM AND KNOW WHY THIS & 41 & 38 \\
AGGRESSION HAPPENS AND TRY TO HELP THEM". & & \\
"MAKE AN OCCURANCE REPORT, CALL THE FAMILY". & 10 & 9 \\
"KEEP CALM IF POSSIBLE". & 9 & 8 \\
"SEVERE AND EXEMPLARY PENALTIES". & 3 & 3 \\
"INDIGNATION". & 2 & 2 \\
TOTAL & 109 & 100 \\
\hline
\end{tabular}

When asked about the relationship with the majority of students, $80 \%$ of the teachers say they have a good relationship, $15 \%$ claim to have a great relationship and 5\% say they have a regular relationship. When questioned if the school has activities / projects to reduce violence, $69 \%$ and $31 \%$ claim to be unaware of these activities.

The Fisher's exact test was applied with a significance level of 5\%, and there was a significant association ( $p=0.0243$ ) between the data relating to those who have suffered some kind of violence with 
the difficulty of controlling indiscipline in the classroom, not even with the majority claiming not to have difficulty controlling the classroom, can we say that these schools have no discipline problems. School violence reaches all teachers, directly or indirectly, regardless of age, sex and duration of training, which infers that no association exists between the profile of the respondents and the act of violence against them.

\section{DISCUSSION}

Education professionals are living in everyday life situations of violence, making them hostages of actions that plague most of the world population ${ }^{19}$. Previously, students respected their teachers, felt affection for them, and took care of the school. Today, most do not care who is there to teach them, and unfortunately respect was left behind by students who prefer to confront the educator and vandalize the schools. Most respondents have a college degree and say they are prepared, in most cases, to train / teach. This perception can be explained by experience, since most are between 41-50 years of age and have over 10 years of teaching experience. But the aggressiveness of some students makes certain teachers change their school or even profession. Regarding the concept of violence in schools, most teachers defines it as any act of physical, verbal or psychological aggression ${ }^{20,21}$. In this study, in the same manner, the majority attributed the understanding of school violence to the concepts mentioned above, ie, humiliations, insults, threats, teachers threatened with rulers, scratched cars, graffiti on the wall of teachers' houses, armed students in the class room, etc.

Cardia $^{4}$ obtained results that contradict that observed in the study, in which $30.1 \%$ strongly agree and $29.2 \%$ somewhat agree that teachers do not know how to deal with indiscipline in the classroom. However, the teachers put themselves in a posture of indifference to situations of violence they experience in the classroom due to the fact that both the teachers, as well as the students, are being violated in front of their wants and needs ${ }^{8}$.

Students in elementary and secondary education are highlighted since they usually verbally assault teachers, causing a decrease in physical violence. Accordingly, in the present study, it was observed that most workers suffer verbal abuse ${ }^{19,22}$. The males show a more aggressive behavior, as observed in the other study. However, one cannot disregard females because they stand out when considering the verbal abuse and others $^{23,24}$.

Violence in public schools is trivialized, leaving some acts as being perceived as violent, which may explain the low frequency of reports of violence in the schools surveyed. In this sense, we realize that teachers are tired of dealing with the disruption in the classroom and with students who ignore the presence of the educator, and also the low pay that devalues this profession $^{25}$.

The lack of a family base can cause some aggressive behavior in adolescents, who take personal problems to school, contributing to the increase in violence in general and even mental health problems such as depression, anxiety, phobias, insomnia and low self-esteem ${ }^{20,26}$.

The school board sometimes omits cases of violence, disregarding the importance of what happened, because the majority of teachers seek help from the board, but a reasonable percentage has not solved the problem, causing an uncomfortable situation for the teacher, since the attacker does not encounter any kind of punishment for his act ${ }^{19}$, which can also be noticed in the present study, in which the majority seeks help from the school board.

Perhaps one of the ways to solve the problem is based on the good relationship between teachers and students, since the majority of the respondents claim to have a good relationship with their students. An adequate and comprehensive relationship between teachers and students is essential to improve school performance $^{23}$.

In addition to a good relationship, intervention projects seek to prevent violence and provide a good living so that they can transform everyday risk into everyday protectors ${ }^{27}$. These activities developed by schools cause a diminution of violence, which can be observed in this study, where the majority confirmed the existence of projects to reduce violence in schools.

The opening of schools on weekends with activities involving teachers, students, and community groups organized by neighborhood residents reduce the crime rates previously observed ${ }^{14}$. A police presence also brings reassurance to teachers and staff, making it a safer school climate conducive to learning. However, the school cannot become dependent on this feature, but must learn how to prevent and resolve violent situations without calling on the police force ${ }^{27}$.

The school's role is to teach academic content and also conduct and citizenship, collaborating in the character building of the students ${ }^{27}$.

However, we must remember that children and adolescents need to have a family present, because without this criterion the school cannot form a good citizen.

\section{CONCLUSION}

It is concluded that violence is present in the school setting, since most respondents reported being a victim of violence and prevailing verbal aggression. These episodes can be attributed to family dysfunction and an inversion of values which generates disrespect against teachers. 


\section{ACKNOWLEDGEMENTS}

Research Foundation of the State of São Paulo FAPESP \#Grant: 11/07570-1

\section{REFERENCES}

1. Brasil. Ministério da Saúde. Secretaria de Vigilância em Saúde. Departamento de Análise de Situação de Saúde. Viva: vigilância de violências e acidentes, 2008 e 2009 / Ministério da Saúde, Secretaria de Vigilância em Saúde, Departamento de Análise de Situação de Saúde. - Brasília: Ministério da Saúde. (Série G. Estatística e Informação em Saúde). 2010

2. Santana EMU, Gomes CAC. Polícia e escola: aparando arestas. Rev Contrapontos - Eletrônica. 2010;10(2):156-65.

3. Silva HH, Castro LV. Formação docente e violência na escola. Psicol Educ. 2008; 26:47-66.

4. Cardia N. Pesquisa nacional, por amostragem domiciliar, sobre atitudes, normas culturais e valores em relação à violação de direitos humanos e violência: um estudo em 11 capitais de estado. São Paulo: Núcleo de Estudos da Violência da Universidade de São Paulo. 2012. Disponível em: http://www.nevusp.org/downloads/down264.pdf [Acesso em 15 abr 2014].

5. Silva KG. Violência em meio escolar: prevenção e combate. Rev do Ministério Público-GO, Goiânia. 2009; 17:107-10.

6. Silva M. A violência da escola na voz de futuros professores: uma probabilidade da produção da cultura da violência em ambientes escolares? Educar em Revista. 2013;49:339-53.

7. Macêdo RMA, Bonfim MCA. Violências na escola. Revista Diálogo Educacional. 2009;9(28):605-18. Retirado de: http://www2.pucpr.br/reol/index.php/DIALOGO? dd1=2836\&dd99=pdf [Acesso em 15 abr 2014].

8. Oliveira ÉCS, Martins STF. Violência, sociedade e escola: da recusa do diálogo à falência da palavra. Psicol. Soc. 2007;19(1):90-98.

9. Camargo AT, Rodrigues CPO, Guimarães MD, Salvado NA. Relatório de Pesquisa do Projeto "SOS Professores". Trabalho de Conclusão de Curso de Jornalismo da Universidade Metodista de São Paulo, Faculdade de Comunicação. São Bernardo dos Campos. 2010. Retirado de: http://issuu.com/marinadantas/docs/pesquisaprojet ososprofessor [Acesso em 13 abr 2014].

10. Sodré CMO, Moura ML, Alexandre IJ. Violência no espaço escolar. Revista Eventos Pedagógicos. 2012;3(2):315-27.

11. Souza KOJ. Violência em escolas públicas e a promoção da saúde: relatos e diálogos com alunos e professores. Rev Bras Promoç Saúde. 2012; 25(1):71-79.
12. Vieira PR. Violência no meio escolar. Rev do Ministério Público-GO, Goiânia. 2009;17:59-62

13. Wilson CM, Douglas KS, Lyon DR. Violence against teachers: Prevalence and consequences. J Interpers Violence. 2011;26:2353-71. doi:10.1177/0886260510383027

14. Espelage DL, Anderman E, Brown V, Jones A, Lane K, McMahon SD et al. Understanding and preventing violence directed agains teachers: Recommendations for a national research, practice and policy agenda. American Psychologist. 2013; 68:75-87. doi:10.1037/a0031307

15. Galand B, Lecocq C, Philippot P. School violence and teacher Professional disengagement. $\mathrm{Br} \mathrm{J}$ Educ Psycol. 2007;77(2): 465-77.

16. Lopes RB, Galvão A. Violências nas escolas: fatores externos e internos. Rev Educare ISEIB. 2005;1(1):152-69.

17. Bardin L. Análise de Conteúdo. (3 ed). São Paulo (SP). 2004

18. Minayo MCS. O desafio do conhecimento. Pesquisa qualitativa em saúde. São Paulo: Hucitec. 2006

19. Levandoski G, Ogg F, Cardoso FL. Violência contra professores de Educação Física no ensino público do Estado do Paraná. Motriz, Rio Claro. 2011; 17(3):374-83.

20. Almeida SMN, Alencar ML, Fonseca ASA. Programa de Mediação de Conflitos Escolares. Actas do X Congresso Internacional GalegoPortuguês de Psicopedagogia. Braga: Universidade do Minho. 2009:368-380. ISBN978-972-8746-71-1.

21. Reddy LA, Espelage DL, McMahon SD, Anderman EM, Lane KL, Brown VE et al. Violence Against Teachers: Case Studies from the APA Task Force, International Journal of School \& Educational Psychology. 2013; 1(4): 231-245, DOI: 10.1080/21683603.2013.837019

22. Rocha KMM, Farias GM, Gurgel AKC, Costa IKF, Freitas MCS, Souza AAM. Violência na escola vivida por professores, funcionários e diretores. Rev Rene. 2012;13(5):1034-44.

23. Abramovay M. Cotidiano das escolas: entre violências. Brasília: UNESCO, Observatório de Violência, Ministério da Educação. 2005.

24. Martins MJD. O problema da violência escolar: uma clarificação e diferenciação de vários conceitos relacionados. Rev Port Educ. 2005; 18(1): 93-115.

25. Silva JMAP, Salles LMFA. A violência na escola: abordagens teóricas e propostas de prevenção. Educar em Revista. 2010;2:217-32.

26. Monteiro EMLM, Brandão Neto W, Gomes IMB, Freitas RBN, Brady CL, Moraes MUB. Violência 
contra criança e adolescente: rompendo o silêncio. Rev Rene. 2009;10(3):107-28.

27. Abramovay M, Cunha AL, Calaf PP. Revelando tramas, descobrindo segredos: violência e convivência nas escolas. Brasília: Rede de Informação Tecnológica Latino-Americana RITLA; Secretaria de Estado de Educação do Distrito Federal - SEEDF. 2009.

\section{CONFLICTS OF INTERESTS}

The authors declare no conflicts of interests.

\section{CORRESPONDING AUTHOR}

Adryana Alves Costa

adryana_alves@hotmail.com>

Received 10/05/2016

Accepted 22/05/2016 